\title{
Research on the influence of environmental pollution control on regional economic growth and labor market
}

\author{
Ren Yuechao ${ }^{1, *}$ \\ ${ }^{1}$ School of Economics and Management, Beijing Jiaotong University, Beijing, CHINA
}

\begin{abstract}
The rapid economic development has made environmental problems increasingly serious. In order to ensure the quality of residents' life, environmental governance investment has been continuously strengthened in China. This paper studies the influence of investment in environmental pollution control on regional economy and labor market in 31 provinces and cities (except Xinjiang Corps) from 2000 to 2018. It is concluded that the impact of environmental pollution control investment on regional economic growth and the local employed personnel average wage is significantly negative, and the impact of environmental pollution control investment on local unemployment rate is significantly positive. In view of this conclusion, some suggestions are put forward from the perspective of the government.
\end{abstract}

\section{Introduction}

Since 1978, with the rapid development of China's economy, China's environmental problems have become increasingly severe. Environmental pollution seems to have become a necessity for economic development. The relationship between environmental pollution and economic growth has always been a focus of research in the field of environmental economics. Foreign scholars Hecker L P et al. analyzed the spillover effect of urban sewage through the spatial econometric model, and found that it had an impact on the economy of neighboring cities [1]. Domestic scholar Song Tao used the environment-economy model to illustrate the correlation between environmental pollution and economic growth with empirical research [2]. Xu Shichun used the panel data of 28 provinces and cities in China from 1990 to 2005 to construct a model containing pollution equation and output equation to analyze the relationship between China's economic growth and environmental pollution [3]. Other scholars have studied environmental quality and economic growth in local areas of China and proposed different types of environmental regulations for different regions. Li Feifei used carbon dioxide emissions and green total factor productivity of the Yangtze River Economic Belt from 2005 to 2017 as indicators for environmental analysis and analyzed the short-term and long-term impacts of environment on economic growth and suggested that different regions implement different environmental regulations [4].

With the improvement of people's requirements for the quality of life, environmental quality has become an indicator to evaluate the quality of life and environmental pollution will affect the labor market. Foreign scholar Ebenstein Avraham believed that environmental pollution affect residents' health and thus affect labor supply [5]. Domestic scholar Zhou Jieqi believed that in the context of local government competition, environmental standards and labor conditions often become the focus of competition in the process of attracting investment, which may lead to the phenomenon of "high pollution and low wages" in the region [6]. Gu ran believes that environmental pollution has a distorting effect on the price of labor. The price of workers is different in regions with different levels of environmental pollution and environmental pollution will affect income distribution [7].

General Secretary Xi Jinping once proposed that "clear waters and green mountains are golden and silver mountains". The state attaches great importance to environmental protection and puts forward a series of measures to solve the problem of environmental pollution. The investment in environmental pollution control in various regions is also increasing continuously. However, there are few studies on the impact of environmental pollution control on regional economic growth and labor market. This paper intends to use panel data to analyze the impact of environmental pollution control on regional economic growth and labor market from the perspective of investment in environmental pollution control in 31 provinces and cities (except Xinjiang Corps) during the 19 years from 2000 to 2018.

\section{Econometric Model and Descriptive Analysis}

\subsection{Variable Selection}

Explained variables: The explained variables in this paper are divided into two aspects, one is the level of

* Corresponding author: 19120556@bjtu.edu.cn 
economic growth, the other is the labor market. Generally speaking, GDP growth rate is a key index to measure the economic growth of a country or region. For the labor market, this article uses two indicators which include the unemployment rate of local residents and the average wage of local employees.

Explain variables: From the perspective of environmental pollution control, two types of indicators are used to measure the degree of environmental pollution control in the article, one is the proportion of environmental pollution control investment in GDP which is an overall index and the index is chosen because the direct comparison of the amount of investment in environmental pollution control between regions is not objective due to their different levels of economic growth. The other index of investment in treatment is divided into three aspects, including investment in treatment of waste water, investment in treatment of waste gas and investment in treatment of solid waste. As we all know, waste water, waste gas and solid waste are the key sources of environmental pollution. The investment in environmental pollution is divided into three aspects to analyze the key points of environmental pollution more clearly.

Control variable: Foreign direct investment is an indicator to measure regional trade. Al-Barakani Abdo's research found that while FDI has an impact on regional economy and it could aggravate environmental pollution [8].Therefore, foreign direct investment is set as the control variable to investigate its impact on economic growth and labor market [9]. Education funds investment is a measure of the level of education in a region. The regions with higher education level have higher labor productivity, faster economic development and more perfect labor market. The consumer price index is an indicator to measure the consumption ability of residents. The consumption level of residents can measure the quality of their life and the economic level. Urban population density is an indicator to measure the size of a region, which is closely related to regional economic growth. The greater the urban population density, the larger the population, will have an impact on the competitiveness of labor force and the wage level. Fixed asset investment is an indicator to measure the infrastructure construction of a region. On the one hand, the improvement degree of infrastructure will affect regional production efficiency and thus regional economic development; on the other hand, regions with more perfect infrastructure will gather a large number of residents and enterprises, thus exerting an impact on the labor market.

\subsection{Variable Selection}

As panel data is used in this study, the following model is constructed to analyze the impact of environmental pollution treatment on regional economic growth and labor market:

$Y_{i t}=\alpha+\beta P E P C I_{i t}+\mu X_{i t}$
$Y_{i t}=\xi+\theta_{1} \ln W W T I_{i t}+\theta_{2} \ln W G T I_{i t}+\theta_{3} \ln S W T I_{i t}+\lambda X_{i t}$

"Y" represents the explained variable associated with economic growth and the labor market and it includes GDP growth rate, the unemployment rate of local residents and average wage of local employees (wan yuan). " $\mathrm{X}$ " represents the control variable and it includes foreign direct investment, education funds investment, the consumer price index, urban population density and fixed asset investment. The core explanatory variable of Equation (1) is the proportion of investment in environmental pollution treatment in GDP. The core explanatory variable of Equation (2) is investment in waste water treatment, waste gas treatment and solid waste treatment. The difference between the two equation is that one measures the overall level of treatment while the other classifies environmental pollution. For the convenience of calculation, part of the data in this paper is analyzed by logarithm.

\subsection{The Data Source}

The data used for variables in this paper are calculated from the inter-provincial panel data of 31 provinces and cities except Hong Kong, Macao and Taiwan from 2000 to 2018 in China Statistical Yearbook of National Bureau of Statistics, provincial statistical yearbook over the years and EPS database. The detailed descriptive analysis is shown in Table 1

Table 1. Statistical descriptive analysis

\begin{tabular}{|c|c|c|c|c|c|c|}
\hline Variable & Code & Number & Mean & Standard & Minimum & Maximum \\
\hline GDP growth rate & GDPgrowth & 589 & 10.167 & 2.752 & 0.5 & 19.6 \\
\hline $\begin{array}{l}\text { The unemployment rate of local } \\
\text { residents }\end{array}$ & LUR & 583 & 24.081 & 14.232 & 1 & 75.6 \\
\hline $\begin{array}{l}\text { Average wage of local } \\
\text { employees (wan yuan) }\end{array}$ & AVEwage & 434 & 5.0363 & 2.48115 & 1.5370 & 16.6803 \\
\hline $\begin{array}{l}\text { The proportion of environmental } \\
\text { pollution control investment in } \\
\text { GDP }\end{array}$ & PEPCI & 465 & 1.330 & 0.701 & 0.05 & 4.66 \\
\hline $\begin{array}{l}\text { Investment in treatment of waste } \\
\text { water }\end{array}$ & $\operatorname{lnWWTI}$ & 582 & 9.951 & 1.388 & 2.708 & 12.596 \\
\hline $\begin{array}{l}\text { Investment in treatment of waste } \\
\text { gas }\end{array}$ & $\ln W G T I$ & 580 & 10.735 & 1.502 & 3.689 & 14.063 \\
\hline $\begin{array}{l}\text { Investment in treatment of solid } \\
\text { waste }\end{array}$ & $\operatorname{lnSWTI}$ & 536 & 7.670 & 1.861 & -2.303 & 12.248 \\
\hline Foreign direct investment & $\operatorname{lnFDI}$ & 372 & 11.493 & 1.981 & 0.693 & 14.983 \\
\hline Education funds investment & $\operatorname{lnEFI}$ & 558 & 15.079 & 1.111 & 11.309 & 17.569 \\
\hline The consumer price index & CPIgrowth & 589 & 2.305 & 1.939 & -3.3 & 10.1 \\
\hline Urban population density & UPD & 589 & 2284.9 & 1356.6 & 26 & 6307.4 \\
\hline Fixed asset investment & $\operatorname{lnFAI}$ & 558 & 8.301 & 1.342 & 4.159 & 10.919 \\
\hline
\end{tabular}




\section{Model Construction and Empirical Analysis}

The empirical results of the impact of environmental pollution control on regional economic growth are shown in Table 2. Model 1 and Model 3 represent the overall impact of environmental pollution control on economic growth. Model 2 and Model 4 represent the impact of environmental pollution control classification on economic growth and Model 3 and Model 4 include control variables. The results show that investment in environmental pollution control has a significant negative impact on regional economic growth. Model 1 shows that the higher the proportion of investment in environmental pollution control in GDP, the slower the economic growth will be. Model 2 shows that the larger the investment in waste water treatment, waste gas treatment and solid waste treatment, the slower the economic growth will be. As far as China is concerned, investment in environmental pollution control has a greater impact on economic development. This trends don't weaken after adding control variables. Meanwhile, investment in education funds and fixed assets had a significant impact on economic growth. Foreign direct investment and consumer price index also have an impact on economic growth.

Table 2. Empirical analysis of environmental pollution control on regional economic growth

\begin{tabular}{|c|c|c|c|c|}
\hline Code & Model 1 & Model 2 & Model3 & Model 4 \\
\hline \multirow{2}{*}{ PEPCI } & $-0.561 * *$ & & $-0.459^{* * *}$ & \\
\hline & $(0.185)$ & & $(0.208)$ & \\
\hline \multirow{2}{*}{$\operatorname{lnWWTI}$} & & $-1.075^{* * *}$ & & $-0.195^{*}$ \\
\hline & & $(0.121)$ & & (0.169) \\
\hline \multirow{2}{*}{$\ln W G T I$} & & $-1.174 * * *$ & & $-0.0441^{* *}$ \\
\hline & & $(0.0963)$ & & $(0.149)$ \\
\hline \multirow{2}{*}{$\operatorname{lnSWTI}$} & & $-0.148^{*}$ & & $-0.129 *$ \\
\hline & & $(0.0656)$ & & $(0.0773)$ \\
\hline \multirow{2}{*}{$\operatorname{lnFDI}$} & & & $0.154 *$ & $0.179 *$ \\
\hline & & & $(0.117)$ & (0.109) \\
\hline \multirow{2}{*}{$\ln E F I$} & & & $-1.860^{* * *}$ & $-1.767 * * *$ \\
\hline & & & $(0.480)$ & $(0.448)$ \\
\hline \multirow{2}{*}{ CPIgrowth } & & & $0.135^{*}$ & $0.420^{* *}$ \\
\hline & & & $(0.0549)$ & $(0.0514)$ \\
\hline \multirow{2}{*}{ UPD } & & & $0.500 *$ & 0.167 \\
\hline & & & $(0.0902)$ & $(0.0872)$ \\
\hline \multirow{2}{*}{$\operatorname{lnFAI}$} & & & $1.207^{* * *}$ & $1.493 * * *$ \\
\hline & & & $(0.423)$ & $(0.394)$ \\
\hline \multirow{2}{*}{ _cons } & $11.12^{* * *}$ & $10.90^{* * *}$ & $28.95^{* * *}$ & $23.96 * * *$ \\
\hline & $(0.278)$ & (1.011) & $(4.232)$ & (3.964) \\
\hline $\mathrm{N}$ & 465 & 536 & 279 & 340 \\
\hline
\end{tabular}

The empirical results on the impact of environmental pollution on local residents unemployment rate are shown in table 3 , the model set up mechanism and is similar to table 2 . The model 5 and model 6 illustrate that the environmental pollution control investment has a significant influence on local residents unemployment. The more investment in environmental pollution control, the higher the unemployment rate of local residents which shows that environmental pollution is closely related to laborer living. After adding the control variables, Model 7 and Model 8 indicate that foreign direct investment, urban population density and fixed asset investment have a greater impact on the unemployment rate of local residents, while education funds investment and consumer price index have a smaller impact on the unemployment rate.

Table 3. Empirical analysis of environmental pollution control on local residents unemployment rate

\begin{tabular}{|c|c|c|c|c|}
\hline Code & Model 5 & Model 6 & Model 7 & Model 8 \\
\hline PEPCI & $\begin{array}{c}5.657^{* * *} \\
(0.908)\end{array}$ & & $\begin{array}{c}5.075^{* * *} \\
(1.074)\end{array}$ & \\
\hline $\operatorname{lnWWTI}$ & & $\begin{array}{c}4.624 * * * \\
(0.587)\end{array}$ & & $\begin{array}{r}4.383^{* * *} \\
(0.840)\end{array}$ \\
\hline $\operatorname{lnWGTI}$ & & $\begin{array}{l}-2.597 \\
(0.466)\end{array}$ & & $\begin{array}{l}0.852^{* *} \\
(0.740)\end{array}$ \\
\hline $\operatorname{lnSWTI}$ & & $\begin{array}{l}0.177^{* *} \\
(0.318)\end{array}$ & & $\begin{array}{l}-0.473 \\
(0.385)\end{array}$ \\
\hline $\operatorname{lnFDI}$ & & & $\begin{array}{l}1.587 * * \\
(0.593)\end{array}$ & $\begin{array}{r}2.883^{* * *} \\
(0.544)\end{array}$ \\
\hline $\ln$ EFI & & & $\begin{array}{l}-0.488^{*} \\
(2.426)\end{array}$ & $\begin{array}{c}-3.975 * * \\
(2.231)\end{array}$ \\
\hline CPIgrowth & & & $\begin{array}{l}-0.125^{*} \\
(0.276)\end{array}$ & $\begin{array}{l}-0.323^{*} \\
(0.256)\end{array}$ \\
\hline UPD & & & $\begin{array}{l}0.142 * * \\
(0.0455)\end{array}$ & $\begin{array}{l}0.118 * * \\
(0.0434)\end{array}$ \\
\hline $\operatorname{lnFAI}$ & & & $\begin{array}{c}1.611^{* * *} \\
(2.130)\end{array}$ & $\begin{array}{r}1.354^{* * *} \\
(1.963)\end{array}$ \\
\hline _cons & $\begin{array}{c}-32.11 * * * \\
(1.371)\end{array}$ & $\begin{array}{c}-48.58^{* * *} \\
(4.897)\end{array}$ & $\begin{array}{c}-45.62 * * * \\
(21.61)\end{array}$ & $\begin{array}{c}-93.62 * * * \\
(19.74)\end{array}$ \\
\hline $\mathrm{N}$ & 461 & 536 & 275 & 340 \\
\hline
\end{tabular}

The empirical results on the impact of environmental pollution treatment on the average wage of local employed personnel are shown in Table 4. The setting mechanism of the model is also similar to that in Table 2 . Model 9 shows that the higher the proportion of environmental pollution treatment investment in GDP, the lower the average wage of local employed personnel. Model 10 shows that the higher the investment in waste water treatment, waste gas treatment and solid waste treatment, the lower the average wage of local employed persons. After adding the control variable, the model 11 and model 12 show that foreign direct investment, education funds investment, the consumer price index, the density of urban population and fixed asset investment on local average wage employment has more significant effect. It means that factors affecting employment personnel salary level is varied which includes micro factors and macro factors. 
Table 4. Empirical analysis of environmental pollution control on the average wage of local employees

\begin{tabular}{|c|c|c|c|c|}
\hline Code & Model 9 & Model 10 & Model 11 & Model 12 \\
\hline \multirow{2}{*}{ PEPCI } & $-0.436 * *$ & & $-0.535 * * *$ & \\
\hline & $(0.159)$ & & $(0.133)$ & \\
\hline \multirow{2}{*}{$\ln W W T I$} & & $-1.018 * * *$ & & $-0.743^{* * *}$ \\
\hline & & $(0.118)$ & & $(0.101)$ \\
\hline \multirow{2}{*}{ lnWGTI } & & $-0.780^{* * * *}$ & & 0.0292 \\
\hline & & $(0.0995)$ & & $(0.0781)$ \\
\hline \multirow{2}{*}{ InSWTI } & & $-0.256 * * *$ & & $-0.0775^{*}$ \\
\hline & & $(0.0640)$ & & $(0.0422)$ \\
\hline \multirow{2}{*}{$\operatorname{lnFDI}$} & & & $0.200^{* *}$ & $0.127^{* *}$ \\
\hline & & & $(0.0774)$ & $(0.0679)$ \\
\hline \multirow{2}{*}{$\operatorname{lnEFI}$} & & & $1.325 * * *$ & $0.866^{* *}$ \\
\hline & & & $(0.314)$ & $(0.261)$ \\
\hline \multirow{2}{*}{ CPIgrowth } & & & $0.0578^{*}$ & $0.0663^{*}$ \\
\hline & & & $(0.0323)$ & $(0.0268)$ \\
\hline \multirow{2}{*}{ UPD } & & & $-0.421^{* *}$ & $-0.155^{*}$ \\
\hline & & & $(0.0576)$ & $(0.0462)$ \\
\hline \multirow{2}{*}{$\operatorname{lnFAI}$} & & & $-1.033^{* * *}$ & $-0.149^{*}$ \\
\hline & & & $(0.275)$ & $(0.240)$ \\
\hline \multirow{2}{*}{ _cons } & $4.160^{* * *}$ & $8.630^{* * *}$ & $11.22 * * *$ & $-4.749 * * *$ \\
\hline & (2.416) & $(1.113)$ & $(2.772)$ & $(2.387)$ \\
\hline $\mathrm{N}$ & 403 & 390 & 217 & 194 \\
\hline
\end{tabular}

\section{Conclusions}

This paper uses relevant panel data from 31 provinces and cities in China to investigate the impact of environmental pollution control on regional economic growth and labor market, and draws the following conclusions: First, the impact of environmental pollution control investment on regional economic growth and the average wage of local employed personnel is significantly negative, while the impact of environmental pollution control investment on the unemployment rate of local residents is significantly positive. That means the more investment in environmental pollution control, the more serious environmental pollution is, and the less conducive to regional economic development and labor employment. The environment pollution has effects on the quality of life of laborers. Second, environmental pollution control investment and foreign direct investment, education funds investment, the consumer price index, the density of urban population, fixed asset investment common impact on regional economic level and the labor market, it shows that the influence of the economic level and labor market of the region where the environmental pollution control investment is made is not unique, or there could be interactions. And there are many topics for further research.

In order to realize the steady growth of regional economic level, China should strictly control the environmental pollution and pay attention to the impact of environmental factors on the labor market. First, factories with serious environmental pollution should take the initiative to bear the social costs caused by environmental pollution, instead of government funding for governance. Secondly, the government should pay attention to the impact of environmental pollution on workers, increase technical and skill training for workers, and raise the average income of employed residents. Finally, the government should balance the relationship between environmental pollution, energy-saving emission reduction mechanisms and labor welfare. And only doing this can prevent workers from paying for environmental pollution. At the same time, the government's input in environmental governance should be greatly reduced.

\section{Acknowledgments}

Thanks for the data support from National Statistical Yearbook of China and EPS database.

\section{References}

1. L. P. Hecker, F. Wtzold, G. Markwardt. (2020) Spotlight on Spatial Spillovers: An Econometric Analysis of Wastewater Treatment in Mexican Municipalities J. Ecological Economics, 175.

2. Song T, Zheng T, Tong L. (2007) Theoretical analysis and econometric test of the correlation between environmental pollution and economic growth J. Scientia Geographica Sinica, 2007(02):156-162.

3. Xu S, He Z. (2007) An empirical analysis of the relationship between economic growth and environmental pollution in China: from 1990-2005 provincial panel data J. Economic restructuring reform, 2007(04):22-26.

4. Li F. (2021) The relationship between the quality of economic growth, environmental quality and environmental regulation: an empirical analysis based on the Yangtze River Economic Belt J. Journal of Zhengzhou Institute of Aeronautical Industry Management, 2021,39(02):13-28.

5. E. B. Avraham, Fan M.Y., G.T. Michael, He G. J., Zhou M. G.. (2017) New evidence on the impact of sustained exposure to air pollution on life expectancy from China's Huai River Policy J. Proceedings of the National Academy of Sciences of the United States of America, 2017,114(39).

6. Zhou Jieqi, Wang Tongsan. (2017) Foreign investment, environmental regulation and environmental efficiency: Theoretical expansion and empirical evidence from China J. Industrial Economics Research, 2017(04):67-79.

7. Gu R, Pu Y.P. (2019) Does environmental pollution exacerbate labor price distortions? J. Industrial Economics Research, 2019(03):101-113. (in Chinese)

8. F. AL-Barakani Abdo, B. Bin Li, X.D. Zhang, J. Lu, B. Abdulwase Rasheed. (2020) Influence of FDI on 
environmental pollution in selected Arab countries: a spatial econometric analysis perspective $\mathrm{J}$. Environmental Science and Pollution Research, 2020,27(22).

9. Xiao Q, Fang S. J. (2019) Empirical analysis of the impact of income gap and environmental pollution on residents' health J. Statistics and Decision Making, 201,37(07):67-71. 